\title{
GRIN2A Gene
}

National Cancer Institute

\section{Source}

National Cancer Institute. GRIN2A Gene. NCI Thesaurus. Code C98146.

This gene is involved in the regulation of ion transport. 